\title{
IMMUNODEPRESSION AS A RISK FACTOR OF INFECTION IN PATIENTS WITH ACUTE ISCHEMIC STROKE
}

\author{
Ken Wirastuti ${ }^{1,2)}$ \\ 1)Faculty of Medicine, Universitas Sultan Agung \\ ${ }^{2)}$ Sultan Agung Islamic Hospital
}

\begin{abstract}
Background: Immunodepression is an absence or deficient supply of the components of either humoral or cellular immunity, or both. Previous studies show that the central nervous system and the immune system interact in complex ways. Better insight into these interactions may be relevant to the treatment of patients with stroke and other forms of central nervous system injury. This study aimed to determine immunodepression as a risk factor of infection in patients with acute ischemic stroke.

Subjects and Method: This was a cohort study conducted in Sultan Agung Islamic Hospital, Semarang, Central Java. A sample of 89 patients with post-acute ischemic stroke who had been hospitalized for $\geq 5$ days was selected for this study as the exposed group and non-stroke patients as non-exposed group. The dependent variable was immunodepression infection as indicated by high leucocytes, high neutrophils, low lymphocytes, low monocytes. The independent variable was post-acute ischemic stroke. The data were obtained from the medical record. The data were analyzed by a chi-square test with Risk Ratio (RR) as the measure of association.

Results: Post-acute ischemic stroke was associated with an increased risk of leucocytosis $(\mathrm{RR}=3.95 \%$; $95 \% \mathrm{CI}=1.59$ to 3.27$)$, neutrophilia $(\mathrm{RR}=1.98$; $95 \% \mathrm{CI}=$ 1.69 to 12.63$)$, lymphocytopenia $(\mathrm{RR}=1.77 ; 95 \% \mathrm{CI}=1.51$ to 1.98$)$, monocytopenia $(\mathrm{RR}=1.85 \% ; 95 \% \mathrm{CI}=1.33$ to 1.92$)$.
\end{abstract}

Conclusion: Acute ischemic stroke increases the risk of infection due to immunodepression.

Keywords: acute ischemic stroke, immunodepression, infection

\section{Correspondence:}

Ken Wirastuti. Faculty of Medicine, Universitas Sultan Agung/ Sultan Agung Islamic Hospital. Email: ken.wirastuti@gmail.com. Mobile: 08122716132. 